\title{
ROLE OF ULTRASOUND AND CT SCAN IN EVALUATING FOCAL LIVER LESIONS
}

Rajesh Rathore ${ }^{1}$, Rajesh Kumar², Sayal Choudhary ${ }^{3}$

${ }^{1}$ Assistant Professor, Department of Radiology, R. D. Gardi Medical College, Ujjain.

${ }^{2} 2^{\text {nd }}$ Year PG Resident, Department of Radiology, R. D. Gardi Medical College, Ujjain.

${ }^{3} 2^{\text {nd }}$ Year PG Resident, Department of Radiology, R. D. Gardi Medical College, Ujjain.

\section{ABSTRACT}

The liver plays several complex but essential roles in the metabolism of amino acids, carbohydrates, and lipids as well as synthesis of proteins. The basic pathophysiology of parenchymal hepatic diseases usually represents a failure in one of these metabolic pathways. ${ }^{1}$ Diagnosis of liver pathology rests on physical examination, laboratory investigation, newer imaging techniques, radio isotope scanning. ${ }^{2}$ etc. Radiological techniques like ultrasonography and CT scan have roles in evaluation of these liver diseases. Ultrasound plays an important role in evaluation of liver pathology. It helps by detecting lesions, gives clue about its internal structure giving idea about its exact extent: it also gives opportunity to evaluate other abdominal organs. Correlation of ultrasonographic findings with clinical data, laboratory investigations and other radiological investigations lead to make a definite and accurate diagnosis. Thus appropriate management of patients can be done. Present study includes focal and pathology. In present years ultrasonography is widely accepted as first line radiological investigation for liver pathology detection. It is noninvasive cheap, quick free of radiation hazards, comfortable for patients. ${ }^{3}$ easy to re-perform and very accurate in hands of skilled operator. With Colour Doppler it is possible to evaluate vascularity of lesion. Ultrasonographic contrast media helps in determination of exact extent of lesion and vascularity of lesion. CT scan is very helpful to evaluate focal as well as diffuse liver pathology. ${ }^{4}$ Other investigations like MRI, radionuclide scanning, DSA. ${ }^{5}$ etc. are also helpful in liver pathology.

\section{KEYWORDS}

Focal Liver Lesion, Ultrasound, CT Scan, Characterization, Lobe Predominance.

HOW TO CITE THIS ARTICLE: Rathore R, Kumar R, Choudhary S. "Role of ultrasound and CT scan in evaluating focal liver lesions." Journal of Evolution of Medical and Dental Sciences 2015; Vol. 4, Issue 104, December 28; Page: 16951-16953,

DOI: $10.14260 /$ jemds $/ 2015 / 2556$

\section{INTRODUCTION}

\section{Statement of Study}

CT scan is the imaging modality of choice for diagnosis and staging of liver pathologies. ${ }^{6}$

\section{MATERIAL AND METHODS}

This study aims at following up patients with liver lesion presenting at Radiology Department by using USG and CT scan so as to achieve aims and objective outlined.

All the patients presented to hospital for the purpose of diagnosis and treatment.

\section{Selection of Patients}

\section{Inclusion Criteria}

1. Only those patients who are willing to participate in study will be included.

2. Patients referred to the radiology department for ultrasonography and/or CT scan abdomen investigation and found to have liver disease, will be included in this study.

3. Already diagnoses cases of such liver disease which need follow up radiological investigations and are referred to our radiology department will be included in study.

4. Patients coming for ultrasonography and CT scan for diseases other than liver disease, and are accidentally found liver to have liver lesion, will be included in this study.

Financial or Other, Competing Interest: None.

Submission 07-12-2015, Peer Review 08-12-2015,

Acceptance 24-12-2015, Published 28-12-2015.

Corresponding Author:

Dr. Rajesh Kumar,

Room No. 511, RMO Hostel,

R. D. Gardi Medical College,

Ujjain.

E-mail: tokasrajesh@gmail.com

DOI:10.14260/jemds/2015/2556

\section{Exclusion Criteria}

1. Patients presenting to radiology department having liver in past and are cured completely will be excluded from the study.

\section{Description of Tools}

1. USG Machine: Mindray DN-C3.

2. CT scan Machine: GE health care 128 slice spiral.

\section{RESULTS}

A total 70 patients were examined and comparison done with operative and histopathological diagnosis. The salient observations are as follows.

\begin{tabular}{|c|c|c|}
\hline Age Group & No. of Patients & Percentage (\%) \\
\hline $00-10$ & 02 & 2.85 \\
\hline $11-20$ & 03 & 4.28 \\
\hline $21-30$ & 10 & 14.28 \\
\hline $31-40$ & 13 & 18.57 \\
\hline $41-50$ & 18 & 25.71 \\
\hline $51-60$ & 12 & 17.14 \\
\hline $61-70$ & 08 & 11.42 \\
\hline $71-80$ & 03 & 4.28 \\
\hline $81-90$ & 01 & 1.42 \\
\hline \multicolumn{3}{|c|}{ Table I: Age Distribution } \\
\hline
\end{tabular}

The youngest patient was 2 months old and the oldest was 85 years old. Maximum numbers of patients were in age group 41-50 years $(25.71 \%)$, minimum numbers of patients were in age group $81-90$ years $(1.42 \%)$.

\begin{tabular}{|c|c|c|}
\hline Sex & No. of Patients & Percentage (\%) \\
\hline Male & 48 & 68.57 \\
\hline Female & 22 & 31.42 \\
\hline \multicolumn{3}{|c|}{ Table II: Sex wise Distribution } \\
\hline
\end{tabular}


In the present study, male patients (68.57\%) were more as compared to female patients (31.42\%).

\begin{tabular}{|c|c|c|}
\hline Lobe Involvement & No. of Patients & Percentage (\%) \\
\hline Right & 30 & 42.85 \\
\hline Left & 12 & 17.14 \\
\hline Both & 28 & 40.00 \\
\hline \multicolumn{2}{|c|}{ Table III: Lobe Wise Distribution } \\
\hline
\end{tabular}

In focal liver pathology evaluation right lobe more commonly involved accounting for (42.85\%) compared to both $(40.00 \%)$ and left lobe involved in $(17.14 \%)$ of cases.

\begin{tabular}{|c|c|c|}
\hline Symptoms & $\begin{array}{c}\text { No. of } \\
\text { Patients }\end{array}$ & $\begin{array}{c}\text { Percentage } \\
\text { (\%) }\end{array}$ \\
\hline $\begin{array}{c}\text { Pain in right } \\
\text { hypochondrium }\end{array}$ & 30 & 42.85 \\
\hline Lump in abdomen & 08 & 11.42 \\
\hline Fever & 12 & 17.14 \\
\hline Jaundice & 09 & 12.85 \\
\hline Weight Loss & 04 & 5.71 \\
\hline Abdominal distention & 13 & 18.57 \\
\hline Dyspnea & 10 & 14.28 \\
\hline Vomiting & 05 & 7.14 \\
\hline Diarrhoea & 01 & 1.42 \\
\hline Dysphagia & 02 & 2.85 \\
\hline Menorrhagia & 02 & 2.85 \\
\hline Heamatemesis & 01 & 1.42 \\
\hline Melena & 01 & 1.42 \\
\hline Testicular swelling & 01 & 1.42 \\
\hline Difficulty in micturition & 02 & 2.85 \\
\hline Per vaginal discharge & 01 & 1.42 \\
\hline Leg swelling & 01 & 1.42 \\
\hline Table IV: Clinical Presentation \\
\hline
\end{tabular}

Pain in the right hypochondrium was the most common presentation with $(42.85 \%)$ of cases followed by abdominal distention with $(18.57 \%)$ of patients.
Minimum number of patients presents with swelling in neck, testicular swelling Menorrhagia, per vaginal discharge.

\begin{tabular}{|c|c|c|c|}
\hline $\begin{array}{c}\text { Sl. } \\
\text { No. }\end{array}$ & Echo Pattern & $\begin{array}{c}\text { No. of } \\
\text { Patients }\end{array}$ & $\begin{array}{c}\text { Percentage } \\
\text { (\%) }\end{array}$ \\
\hline 1. & Anechoic & 10 & 14.28 \\
\hline 2. & Hypo echoic & 22 & 31.42 \\
\hline 3. & Echogenic & 09 & 12.85 \\
\hline 4. & Mix echogenic & 12 & 17.14 \\
\hline 5. & $\begin{array}{c}\text { Coarse echo } \\
\text { pattern }\end{array}$ & 10 & 14.28 \\
\hline 6. & Target lesions & 05 & 7.14 \\
\hline \multicolumn{3}{|c|}{ Table V: Ultrasound Pattern } \\
\hline
\end{tabular}

Hypo echoic lesions were common with $(31.42 \%)$ of patients to be followed by mix echogenic lesion with $(17.14 \%)$ of patients. The last common target lesions with $(7.14 \%)$ of patients.

\begin{tabular}{|c|c|c|c|}
\hline $\begin{array}{c}\text { Sl. } \\
\text { No. }\end{array}$ & $\begin{array}{l}\text { Type of } \\
\text { Lesions }\end{array}$ & $\begin{array}{c}\text { No. of } \\
\text { Patients }\end{array}$ & $\begin{array}{c}\text { Percentage } \\
(\%)\end{array}$ \\
\hline 1. & Benign & 45 & 64.28 \\
\hline 2. & Malignant & 25 & 35.71 \\
\hline & Total & 70 & 100 \\
\hline
\end{tabular}

(Total number of patients $=70$ )

Benign lesions were more common than malignant lesions. Benign lesions were found $64.3 \%$ and malignant lesions were found $35.7 \%$ of the total patients.

\section{DISCUSSION}

In the present study, 70 cases of liver pathology were studied by using various radio-imaging modalities and the results were compared with the previous studies.

\begin{tabular}{|c|c|c|c|c|c|c|c|c|c|}
\hline Series & $\mathbf{0 - 1 0}$ & $\mathbf{1 1 - 2 0}$ & $\mathbf{2 1 - 3 0}$ & $\mathbf{3 1 - 4 0}$ & $\mathbf{4 1 - 5 0}$ & $\mathbf{5 1 - 6 0}$ & $\mathbf{6 1 - 7 0}$ & $\mathbf{7 1 - 8 0}$ & $\mathbf{8 1 - 9 0}$ \\
\hline Dalsania et al. & 1.43 & 10.0 & 20.0 & 14.28 & 17.14 & 22.86 & 7.14 & 7.14 & 0.0 \\
\hline Vasani et al. & 1.42 & 4.28 & 15.77 & 14.28 & 21.45 & 27.14 & 11.42 & 4.28 & 0.0 \\
\hline Present series & 2.85 & 4.28 & 14.28 & 18.57 & 25.71 & 17.14 & 11.42 & 4.28 & 1.42 \\
\hline \multicolumn{8}{|c|}{ Table 1: Comparative Study for Sex Distribution } \\
\hline
\end{tabular}

In both Dalsania et al. and Vasani et al. series maximum number of patients was I (51-60 years) age group. In the present study maximum number of patients was in (41-50 years) age group (25.71\% of total patients followed by (31-40 years) age group $(18.57 \%$ of total patients). Above comparative study shows that liver pathologies are more common in middle age as compared to paediatrics and old age. $^{7}$

\begin{tabular}{|c|c|c|c|}
\hline Series & Male & Female & Ratio of (M:F) \\
\hline Dalsania et al. & 61.42 & 38.58 & $1.5: 1$ \\
\hline Vasani et al. & 80.00 & 20.0 & $4: 1$ \\
\hline Present series & 69.01 & 30.99 & $2.2: 1$ \\
\hline Table 2: Comparative Study for Age Distribution \\
\hline
\end{tabular}

From above table it is evident that male were seem to be more affected than female. In Dalsania et al series male: female was 1.5:1. In Vasani et al series male: female ratio 4:1 while in present study male: female ratio was 2.2:1.

\begin{tabular}{|c|c|c|c|}
\hline Series & Right Lobe & Left Lobe & Both Lobe \\
\hline Mahajan et al. & 77.00 & 22.0 & 03.00 \\
\hline Dalsania et al. & 65.72 & 07.14 & 27.14 \\
\hline Vasani et al. & 45.72 & 14.28 & 40.00 \\
\hline Present series & 42.85 & 17.14 & 40.00 \\
\hline
\end{tabular}

\section{Table 3: Comparative Study for Lobe Distribution}

In the study of Mahajan et al. right lobe was most commonly affected to be followed left lobe, while in Dalsania et al. and Vasani et al. and present study right lobe is most commonly affected followed by both lobes and left lobe involvement was least common. One possible reason for right lobe predominance could be large surface area and greater blood supply to right than left lobe. ${ }^{8}$

\begin{tabular}{|c|c|c|}
\hline Series & Benign & Malignant \\
\hline Dalsania et al. & 55.72 & 44.28 \\
\hline Vasani et al. & 57.14 & 42.86 \\
\hline Present study & 64.28 & 35.71 \\
\hline $\begin{array}{c}\text { Table 4: Comparative Study for Incidence } \\
\text { of Benign and Malignant Lesions }\end{array}$ \\
\hline
\end{tabular}


From above comparison it is evident that benign $(64.28 \%)$ are more common as compare to malignant lesion (35.71\%) in Dalsania et al., Vasani et al. and present study.

\section{CONCLUSION}

1. Ultrasound by the virtue of non-invasiveness, lack of radiation and by ability to demonstrate structural changes in organ is investigation of choice in liver pathology.

2. Ultrasound can easily detect solid to cystic lesions and characterize the size, shape and extent of lesion.

3. Computerized tomography is particularly useful to know the enhancement pattern of the lesion, i.e. centripetal and delayed enhancement pattern of haemangioma can be differentiated from metastatic and focal fatty changes. ${ }^{9}$

4. Computerized tomography is useful to determine density of a particular lesion. So useful in detection of calcification, hemorrhage, fatty changes clear and purulent fluid. ${ }^{10}$

5. Computerized tomography is useful exact determination of the extent of particular lesion and useful to determine staging of malignant lesions. ${ }^{11}$

6. Computerized tomography having radiation exposure, so cannot be safely used in pregnant ladies and children.

\section{REFERENCES}

1. Okano K, Yamamoto J, Okabayashi T, Sugawara Y, Shimada K, Kosuge T, et al. (2002). CT imaging of intrabiliary growth of colorectal liver metastases: a comparison of pathological finding of resected specimens, British Journal of Radiology 75 (2002), 497501.
2. Grainger RG, Allison DJ, Andreas Adam, et al. Diagnostic radiology, $6^{\text {th }}$ edition, vol 1:735-740.

3. David Zakim and Thomas D. Boyer reviewed by DH Adams (2003), Hepatology: a Textbook of Liver Disease, $4^{\text {th }}$ edition, Saunders, 2003. Aug 2003, Vol. 52 Issue 8, p1230.

4. David Sutton, Richard W Whitehouse, Jeremy PR Jenkins. Textbook of radiology and imaging, $7^{\text {th }}$ edition, Vol.1.348-350.

5. Van Leeuwen MS, Noordzij J, Fernandez MA, Hennipman A, Feldberg MA, Dillon EH: Portal venous and segmental anatomy of the right hemiliver: observations based on three-dimensional spiral CT renderings: American Journal of Roentgenology. 163:1395-1404.

6. John R Haaga, Vikram S Dogra, Michael Forsting, et al. CT and MRI imaging of whole body, $5^{\text {th }}$ edition: 1163-1165.

7. Leon Schiff, Eugene Schiff, Schiff R: Diseases of the liver, $6^{\text {th }}$ edition:760-763.

8. Hsien-Ping Lin, Wei-Chi Ho, Cheng-Chi Lee, et al: Infected Simple Hepatic Cysts-3 Cases Report: J Intern Med Taiwan 2009;20:373-377.

9. Vachha et al. Cystic Lesions of the Liver Am J Roentgenol. 2011;196:W355-W366.

10. Barnes PF, DeCock KM, Reynolds TN, et al. A comparison of amoebic and pyogenic abscess of liver. Medicine 1987;66:472-483.

11. Mortele KJ, Ros PR. Cystic focal liver lesions in the adult: differential CT and MR imaging features. Radio Graphics 2001;21(4):895-910. 